\title{
Effectiveness of Health Promotion by Indonesian Breastfeeding Association in Increasing Exclusive Breastfeeding Practice in Surabaya City, East Java
}

\author{
Diani Octaviyanti Handajani'1), Eti Poncorini Pamungkasari²), \\ Uki Retno Budihastuti3) \\ ${ }^{1)}$ Masters Program in Public Health, Universitas Sebelas Maret \\ 2)Faculty of Medicine, Universitas Sebelas Maret \\ 3)Department of Obstetrics and Gynecology, Dr. Moewardi Hospital, Surakarta
}

\begin{abstract}
Background: Breastfeeding is essential for health, development, and child survival by preventing child illness. However, exclusive breastfeeding has not reached the desired target. Health promotion by Indonesian Breastfeeding Association (AIMI) participation is one way to increase exclusive breastfeeding coverage. There are several causative factors that influence exclusive breastfeeding, which can be explained by the PRECEDE-PROCEED model. This study aimed to determine the effectiveness of health promotion through the Association of Indonesian Breastfeeding Mothers (AIMI) in increasing exclusive breastfeeding practice in Surabaya, East Java.

Subjects and Method: This was an analytic observational study with a cohort retrospective design. The study was conducted at AIMI Surabaya branch office and 6 community health centers in Surabaya, East Java, from December 2017 and January 2018. A total sample of 120 lactating mothers was selected for this study by simple random sampling. The dependent variable was breastfeeding. The independent variables were AIMI participation, maternal maternal knowledge, maternal education, maternal attitude, family support, and peer support. The data were collected by questionnaire and analyzed by path analysis.

Results: Exclusive breastfeeding increased with AIMI participation $(b=1.02 ; 95 \% \mathrm{CI}=-0.19$ to 2.24; $\mathrm{p}=0.101)$, better maternal knowledge $(\mathrm{b}=1.48 ; 95 \% \mathrm{CI}=0.15$ to $2.79 ; \mathrm{p}=0.029)$, positive maternal attitude $(b=2.22 ; 95 \% \mathrm{CI}=1.03$ to $3.38 ; \mathrm{p}<0.001)$, and stronger family support $(\mathrm{b}=2.69$; $95 \% \mathrm{CI}=1.25$ to $4.11 ; \mathrm{p}<0.001)$. Maternal attitude increased with AIMI participation $(\mathrm{b}=0.69 ; 95 \%$ $\mathrm{CI}=-0.18$ to $1.57 ; \mathrm{p}=0.116)$, better maternal knowledge $(b=1.56 ; 95 \% \mathrm{CI}=0.72$ to $2.39 ; \mathrm{p}<0.001)$, and higher maternal education $(\mathrm{b}=0.71 ; 95 \% \mathrm{CI}=-0.11$ to $1.52 ; \mathrm{p}=0.089)$. AIMI participation increased with higher education $(b=1.07 ; 95 \% \mathrm{CI}=0.26$ to $1.87 ; \mathrm{p}=0.009)$. Family support increased with stronger peer support $(b=2.24 ; 95 \% \mathrm{CI}=0.73$ to $3.75 ; \mathrm{p}=0.004)$.
\end{abstract}

Conclusion: Exclusive breastfeeding increases with AIMI participation, better maternal knowledge, positive maternal attitude, and stronger family support.

Keywords: exclusive breastfeeding, PRECEDE-PROCEED model, Indonesian Breastfeeding Association (AIMI)

\section{Correspondence:}

Diani Octaviyanti Handajani. Masters Program in Public Health, Universitas Sebelas Maret, Jl. Ir. Sutami 36 A, Surakarta 57126, Central Java. Email: diani.octaviyanti@gmail.com.

Mobile: +628563328666

\section{BACKGROUND}

Exclusive breastfeeding is one of the foundations of health, development and especially of the child survival. Exclusive breastfeeding avoids children from diseases such as diarrhea, pneumonia, and malnutrition, which is a common cause of child mortality under 5 years (WHO, 2017). Early breastfeeding initiation and subsequent 
Journal of Health Promotion and Behavior (2018), 3(1): 1-15

https://doi.org/10.26911/thejhpb.2018.03.01.01

exclusive breastfeeding is one way to prevent such diseases. Breastmilk is the best food for infants aged up to 6 months of life since consists of all the necessary nutrients including protein, carbohydrate, fat, vitamin, and minerals (Fikawati et al., 2015).

World Health Organization (WHO) reported that the coverage of exclusive breastfeeding globally was only $38 \%$ (WHO, 2017). The corresponding exclusive breastfeeding coverage in Indonesia was $55.7 \%$ in 2015. This figure was far below the intended national target of $80 \%$. The corresponding breastfeeding coverage in East Java in 2015 was $68.8 \%$. This figure was lower than that of 2014 (Provincial Health Office East Java, 2015). The breastfeeding coverage in Surabaya was 64.99\% in 2015 (Municipal Health Office Surabaya, 2015).

Infants who do not receive exclusive breastfeeding have 3.9 times as many risk of dying in those who received exclusive breastfeeding (Ekawati et al., 2015).

As studies have shown, factors associated with provision of exclusive breastfeeding included maternal knowledge, motivation, maternal attitude, maternal employment, family support, counselling, exclusive breastfeeding campaign, formula milk campaign, and role of the health worker (Irma and Kustati, 2013; Wulandari, 2015).

A study by Montgomery (2011) reported that knowledge increased exclusive breastfeeding. Mothers with better knowledge were 3 times more likely to breastfeed than those with poorer knowledge (Rachmad, 2011). Family support boosted maternal self confidence to provide exclusive breastfeeding (Mannion et al., 2013).
Exclusive breastfeeding is essential for optimal infant growth and development, including child intelligence.

The East Java government has attempted to socialize and campaign exclusive breastfeeding. It collaborated with supportive groups of exclusive breastfeeding to promote and disseminate information to mothers in exclusive breastfeeding. It also implemented such activities as counselling, exclusive breastfeeding class, and leaflet dissemination, in order to increase exclusive breastfeeding coverage.

A study by Abba et al. (2010) reported that mothers and their families were lacking in exclusive breastfeeding information from the health workers. A study by Gupta et al. (2004) in Uganda concluded that the more mass media information on exclusive breastfeeding, the higher proportion of exclusive breastfeeding.

Another initiative to increase the coverage of exclusive breastfeeding was implementing Indonesian Association of Lactating Mothers (AIMI). AIMI is a not for profit organization of lactating mothers. The purpose of AIMI was to disseminate and improve knowledge on exclusive breastfeeding as well as to increase exclusive breastfeeding coverage in Indonesia.

AIMI advocates and support lactating mothers (Housniati, 2016). The AIMI program included breastfeeding classes, complementary breastfeeding classes, online and offline counselling, breastfeeding week, bazaar, and seminar. AIMI allows mothers to interact and raise question and answer on exclusive breastfeeding issues. As such, mothers become motivated to continue exclusive breastfeeding (Siregar, 2014).

In line with this background the author was interested to examine the effectiveness of AIMI in improving 
exclusive breastfeeding coverage in Surabaya, East Java, Indonesia.

\section{SUBJECTS AND METHOD}

\section{Study design}

This was an analytic observational study with a case control design. The study was conducted at Indonesian Association of Lactating Mothers (AIMI) branch office, Surabaya and 6 community health centers in Surabaya, East Java, from December 2017 to January 2018.

\section{Population and sample}

The case population of this study was all lactating mothers in Surabaya who had infants aged 6 to 12 months and participated in AIMI program. The control population was all lactating mothers in Surabaya who had infants aged 6-12 months and did not follow AIMI program.

A sample of 120 lactating mothers who had infant aged 6 to 12 months was selected for this study by fixed exposure sampling. This sample of lactating mothers included 40 mothers participated in AIMI and 80 mothers did not participate in AIMI.

\section{Study variabel}

The dependent variable was exclusive breastfeeding. The independent variables were AIMI participation, maternal knowledge, maternal education, maternal attitude, family support, and peer support.

\section{Operational definition of variable}

Exclusive breastfeeding was defined as provision of breast milk to infants for 6 months of life, with no other food or drink, not even water, except breast milk (including milk expressed or from a wet nurse). During provision of breast milk the infants may receive oral rehydration salt, drops, and syrups (vitamins, minerals, and medicines). The data were collected by questionnaire. The measurement scale was categorical coded o for not exclusive breastfeeding and 1 for exclusive breastfeeding.

AIMI participation was defined as maternal participation in breastfeeding promotion activities conducted by AIMI Surabaya branch office. The data were collected by questionnaire. The measurement scale was categorical, coded o for did not participate in AIMI and 1 for participated in AIMI.

Maternal knowledge was defined as knowledge of the mother related to exclusive brestfeeding, early breastfeeding initiation management, benefit of exclusive breastfeeding, risk of formula milk, breastfeeding support, breastfeeding position and attachment, and maternal preparation for work. The data were collected by questionnaire. The measurement scale was continuous, but for the purpose of data analysis it was transformed into dichotomous coded o for poor knowledge and 1 for good knowledge.

Maternal education was defined as the highest level of formal education attained by the mother. The data were collected by questionnaire. The measurement scale was categorical and divided into dichotomous, coded $\mathrm{o}$ for $<$ senior high school and 1 for $\geq$ senior high school.

Maternal attitude was defined as maternal positive or negative assessment of exclusive breastfeeding that would maternal decision in giving exclusive breastfeeding to her child. The data were collected by questionnaire. The measurement scale was continuous, but for the purpose of data analysis it was transformed into dichotomous coded $\mathrm{o}$ for negative attitude and 1 for positive attitude.

Family support was defined as family support for mother to give exclusive breastfeeding to her child. The data were collected by questionnaire. The measurement scale was continuous, but for the 
Journal of Health Promotion and Behavior (2018), 3(1): 1-15

https://doi.org/10.26911/thejhpb.2018.03.01.01

purpose of data analysis it was transformed into dichotomous coded o for weak family support and 1 for strong family support.

Peer support was defined as support provided by a group of lactating mothers to support mother to give exclusive breastfeeding. The data were collected by questionnaire. The measurement scale was continuous, but for the purpose of data analysis it was transformed into dichotomous coded o for weak peer support and 1 for strong peer support.

\section{Study instrument}

Table 1 showed the results of reliability test of the instruments collecting data on maternal knowledge, maternal attitude, family support, and peer support. The item total correlation of each item in all of these variables exceeds $\mathrm{r} \geq 0.20$, indicating sufficient internal consistency. In addition, the Alpha Cronbach of each of these variables exceeds $\alpha \geq 0.70$, confirming that the minimum requirement of internal consistency was met.

Table 1. The results of reliability test of the instruments collecting data on maternal knowledge, maternal attitude, family support, and peer support

\begin{tabular}{llccc}
\hline No & \multicolumn{1}{c}{ Variable } & $\begin{array}{c}\text { Number of } \\
\text { question }\end{array}$ & $\begin{array}{c}\text { Item Total } \\
\text { Correlation (r) }\end{array}$ & $\begin{array}{c}\text { Alpha } \\
\text { Cronbach }\end{array}$ \\
\hline $\mathbf{1}$ & Knowledge & 20 & 0.67 & 0.86 \\
$\mathbf{2}$ & Attitude & 13 & 0.30 & 0.87 \\
3 & Family support & 12 & 0.37 & 0.87 \\
4 & Peer support & 13 & 0.33 & 0.82 \\
\hline
\end{tabular}

\section{Data analysis}

Path analysis was used to determine the magnitude of effect of direct and indirect variables on exclusive breastfeeding. The path analysis steps included:
a. Model specification
b. Model identification
c. Model fit
d. Parameter estimation
e. Respecification

\section{Research ethics}

The research ethical clearance for this study was obtained from the Research Ethics Committee at Dr. Moewardi Hospital, Surakarta, Central Java, Indonesia. The ethical clearance for this study was stated in the letter number: 1.103 / XII / HREC / 2017. The research ethics included informed consent, anonimity, and confidentiality.

\section{RESULTS \\ 1. Sample characteristics \\ Table 1 shows that approximately half of the mothers studied were $\geq 28$ years old and}

multiparous. Approximately two-thirds of the mothers studied worked in the home. About half of the infants studied were $\geq 9$ months old.

Table 2. Sample characteristics

\begin{tabular}{lcc}
\hline Characteristics & n & \% \\
\hline Maternal age & & \\
$<28$ years & 57 & 47.5 \\
$\geq 28$ years & 63 & 52.5 \\
$\begin{array}{l}\text { Infant age } \\
<9 \text { months }\end{array}$ & 59 & 49.2 \\
$\begin{array}{l}\text { >9 months } \\
\text { Parity }\end{array}$ & 61 & 50.8 \\
$\begin{array}{l}\text { Primiparous } \\
\begin{array}{l}\text { Multiparous } \\
\text { Maternal }\end{array}\end{array}$ & 56 & 46.7 \\
employment & 64 & 53.3 \\
$\begin{array}{l}\text { Mother working in } \\
\text { house }\end{array}$ & 80 & 66.7 \\
$\begin{array}{l}\text { Mother working } \\
\text { outside the house }\end{array}$ & 40 & 33.3 \\
$\begin{array}{l}\text { Family income } \\
<\text { Rp 4,500,ooo }\end{array}$ & & \\
$\begin{array}{l}\text { Rp 4,500,ooo } \\
\text { Breastfeeding } \\
\text { duration }\end{array}$ & 58 & 48.3 \\
$<8$ times/day & 62 & 51.7 \\
$\geq 8$ times/day & & \\
\hline
\end{tabular}


Table 3. Distribution of study variables

\begin{tabular}{lll}
\hline Characteristics & Frequency (n) & Percent (\%) \\
\hline $\begin{array}{l}\text { Maternal education } \\
\text { Low (<senior high school) }\end{array}$ & 54 & \\
$\quad$ High ( $\geq$ senior high school) & 66 & 45.0 \\
Participation in AIMI & & 55.0 \\
$\quad$ Did not participate & 80 & 66.7 \\
$\quad$ Participate & 40 & 33.3 \\
Maternal knowledge & & \\
$\quad$ Low (score <18) & 69 & 57.5 \\
$\quad$ High (score $\geq 18$ ) & 51 & 42.5 \\
Maternal attitude & & \\
$\quad$ Negative (score <46) & 54 & 45.0 \\
$\quad$ Positive (score $\geq 46)$ & 66 & 55.0 \\
Family support & & \\
$\quad$ Weak (score <12) & 69 & 57.5 \\
$\quad$ Strong (score $\geq 12)$ & 51 & 42.5 \\
Peer support & & \\
$\quad$ Weak (score $<12)$ & 21 & 82.5 \\
$\quad$ Strong (score $\geq 12)$ & 99 & 30 \\
Exclusive breastfeeding & & 70 \\
$\quad$ Non-exclusive breastfeeding & 36 & \\
$\quad$ Exclusive breastfeeding & 84 & \\
\hline
\end{tabular}

2. Bivariate analysis

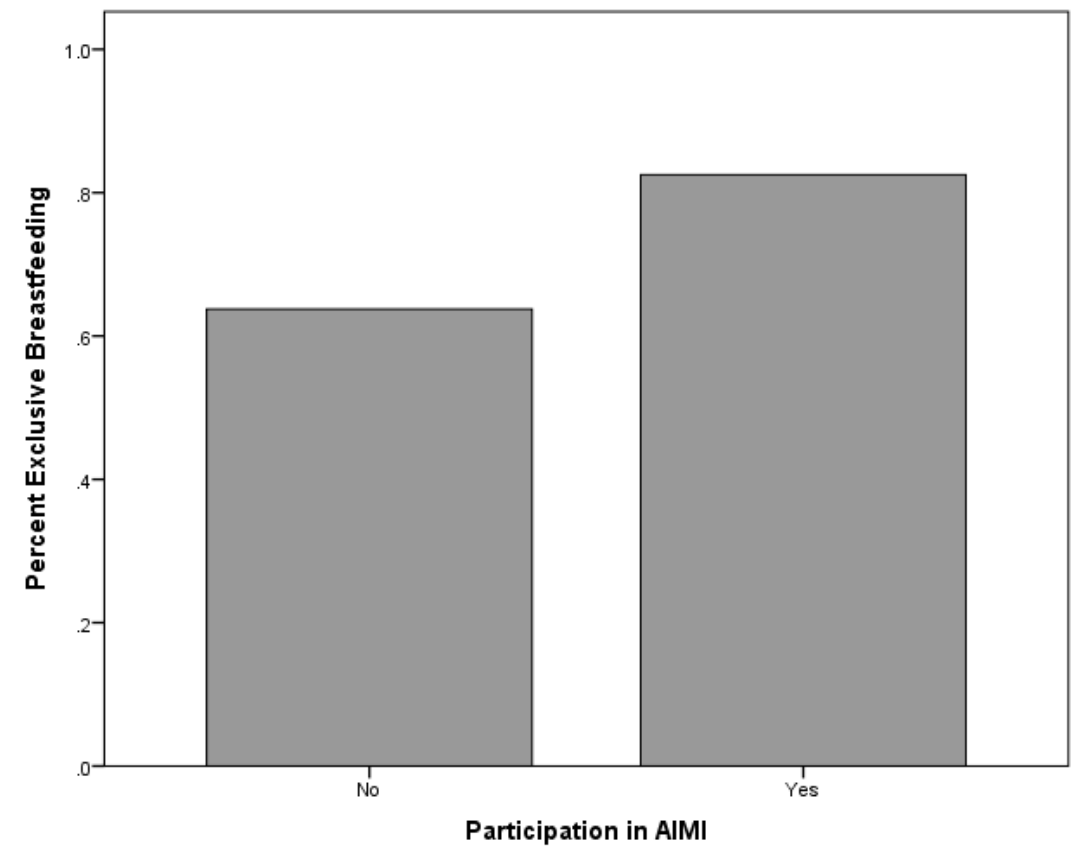

Figure 1. Percent of Exclusive Breastfeeding in Lactating Mothers Who Participated and Did not Participate in the Indonesian Association of Lactating Mother (AIMI) 
Journal of Health Promotion and Behavior (2018), 3(1): 1-15

https://doi.org/10.26911/thejhpb.2018.03.01.01

Figure 1 showed that percent of exclusive breastfeeding was higher in mothers who participated in AIMI than those who did not. It suggests that AIMI successfully increase the prevalence of exclusive breastfeeding.

\section{Path analysis}

The model specification described the relationship between the variables. The observed variables were exclusive breastfeeding, maternal participation in AIMI, maternal knowledge, maternal education, maternal attitude, family support, and peer support.

The model identification was carried out by adding up the number of observed variables, which was substracted by the number of endogenous variables, exogenous variables, and parameters to be estimated. The degree of freedom (df) for this path model was as follows:

a. Number of observed variables: 7

b. Number of endogenous variables: 4

c. Number of exogenous variables: 3

d. Number of parameters: 9

The formula for the degree of freedom was as follows:

$\mathrm{df}=$ (number of observed variables $\mathrm{x}$ (number of observed variables+1) / 2) - (number of endogenous variables + number of exogenous variables + number of parameters)

$$
\begin{aligned}
& =28-16 \\
& =12
\end{aligned}
$$

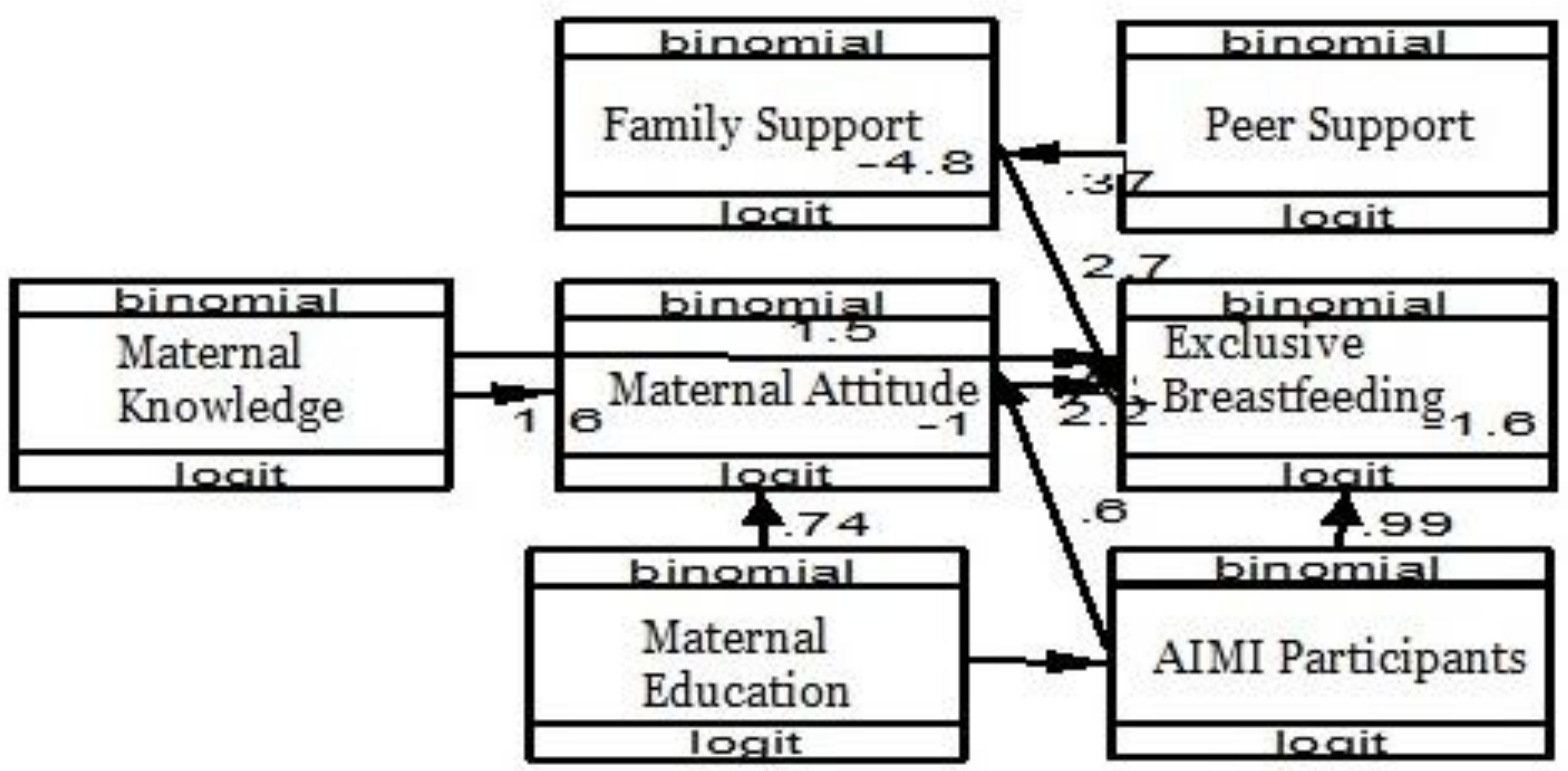

Figure 1. Structural model with estimate

Table 2 shows that maternal participation in AIMI $(b=1.02 ; 95 \% \mathrm{CI}=-0.19$ to 2.24; $\mathrm{p}=0.101$ ), good maternal knowledge $(\mathrm{b}=1.48 ; 95 \% \mathrm{CI}=0.15$ to $2.79 ; \mathrm{p}=0.029)$, positive maternal attitude $(b=2.22 ; 95 \%$ $\mathrm{CI}=1.03$ to $3.38 ; \mathrm{p}<0.001)$, and strong family support $(b=2.69 ; 95 \% \mathrm{CI}=1.25$ to 4.11; $\mathrm{p}<0.001$ ) were positively associated with exclusive breastfeeding.
Maternal participation in AIMI $(\mathrm{b}=$ $0.69 ; 95 \% \mathrm{CI}=-0.18$ to $1.57 ; \mathrm{p}=0.116)$, good maternal knowledge $(\mathrm{b}=1.56 ; 95 \% \mathrm{CI}=$ 0.72 to $2.39 ; \mathrm{p}<0.001$ ), and high maternal education $(b=0.71 ; 95 \% \mathrm{CI}=-0.11$ to 1.52 ; $\mathrm{p}=0.089$ ) were positively associated with maternal positive attitude.

Maternal education was positively associated with maternal participation in 
AIMI $(b=1.07 ; 95 \% \mathrm{CI}=0.26$ to $1.87 ; \mathrm{p}=$ o.009). Peer support was positively asso- ciated with family support $(b=2.24 ; 95 \%$

$\mathrm{CI}=0.73$ to $3.75 ; \mathrm{p}=0.004$ ).

Table 4. Results of path analysis on the effectiveness of AIMI on increasing exclusive breastfeeding

\begin{tabular}{|c|c|c|c|c|c|c|}
\hline \multirow{2}{*}{$\begin{array}{l}\text { Dependent } \\
\text { variable }\end{array}$} & \multirow{2}{*}{\multicolumn{2}{|c|}{ Independent variable }} & \multirow[b]{2}{*}{ b } & \multicolumn{2}{|c|}{$95 \% \mathrm{CI}$} & \multirow[b]{2}{*}{$\mathbf{p}$} \\
\hline & & & & $\begin{array}{c}\text { Lower } \\
\text { limit }\end{array}$ & $\begin{array}{l}\text { Upper } \\
\text { limit }\end{array}$ & \\
\hline \multicolumn{7}{|l|}{ Direct Effect } \\
\hline $\begin{array}{l}\text { Exclusive } \\
\text { breastfeeding }\end{array}$ & $\leftarrow$ & $\begin{array}{l}\text { Maternal participation in } \\
\text { AIMI }\end{array}$ & 1.02 & -0.19 & 2.24 & 0.101 \\
\hline $\begin{array}{l}\text { Exclusive } \\
\text { breastfeeding }\end{array}$ & $\leftarrow$ & $\begin{array}{l}\text { Maternal education } \geq \text { senior } \\
\text { high school }\end{array}$ & 1.48 & 0.15 & 2.79 & 0.029 \\
\hline $\begin{array}{l}\text { Exclusive } \\
\text { breastfeeding }\end{array}$ & $\leftarrow$ & Positive maternal attitude & 2.22 & 1.03 & $3 \cdot 38$ & $<0.001$ \\
\hline $\begin{array}{l}\text { Exclusive } \\
\text { breastfeeding }\end{array}$ & $\leftarrow$ & Strong family support & 2.69 & 1.25 & 4.11 & $<0.001$ \\
\hline \multicolumn{7}{|l|}{ Indirect Effect } \\
\hline $\begin{array}{l}\text { Positive maternal } \\
\text { attitude }\end{array}$ & $\leftarrow$ & $\begin{array}{l}\text { Maternal participation in } \\
\text { AIMI }\end{array}$ & 0.69 & -0.18 & 1.57 & 0.116 \\
\hline $\begin{array}{l}\text { Positive maternal } \\
\text { attitude }\end{array}$ & $\leftarrow$ & Good maternal knowledge & 1.56 & 0.72 & 2.39 & $<0.001$ \\
\hline $\begin{array}{l}\text { Positive maternal } \\
\text { attitude }\end{array}$ & $\leftarrow$ & $\begin{array}{l}\text { Maternal education } \geq \text { senior } \\
\text { high school }\end{array}$ & 0.71 & -0.11 & 1.52 & 0.089 \\
\hline $\begin{array}{l}\text { Maternal } \\
\text { participation in AIMI }\end{array}$ & & $\begin{array}{l}\text { Maternal education } \geq \text { senior } \\
\text { high school }\end{array}$ & 1.07 & 0.26 & 1.87 & 0.009 \\
\hline $\begin{array}{l}\text { Strong family support } \\
\text { n Observation }=120 \\
\text { Log Likelihood }=-261.12\end{array}$ & $\leftarrow$ & Strong peer support & 2.24 & 0.73 & $3 \cdot 75$ & 0.004 \\
\hline
\end{tabular}

\section{DISCUSSION}

1. The association between maternal participation in AIMI and exclusive breastfeeding

The results of this study indicated there was a positive relationship between AIMI participation and exclusive breastfeeding. AIMI participation increased the likelihood of exclusive breastfeeding although it was statistically insignificant. This study is consistent with the study of Alfianrisa et al. (2017) which stated that AIMI's participation had a positive relationship with the increased likelihood of exclusive breastfeeding.

A study conducted by Lakshmi (2011) cited by Alfianrisa et al. (2017) explained that maternal support groups significantly increased activity in the group and would increase 2 times likelihood of mothers to exclusively breastfeed. It was expected that the knowledge and skills of mothers who participated in AIMI would increase their exclusive breastfeeding practice. Ambarwati et al. (2017) reported that mothers who attended discussion and education classes about breastfeeding increased their chance of exclusive breastfeeding practice.

Increased exclusive breastfeeding also increased due to exclusive breastfeeding promotion interventions (Haroon et al., 2013). The study of Haroon et al. (2013) explained that exclusive breastfeeding increased was due to the fact that mothers realized the importance of not introducing formula milk or non-nutritious foods in the early infant life.

A comprehensive breastfeeding edu- 
Journal of Health Promotion and Behavior (2018), 3(1): 1-15

https://doi.org/10.26911/thejhpb.2018.03.01.01

cation intervention is an effort to improve the success of exclusive breastfeeding. These interventions determine the success of a mother in breastfeeding her infant so as to meet the nutritional need of infants (Nurbaeti and Lestari, 2013).

The result of this study is consistent with previous studies and PRECEDEPROCEED theory. Participation in AIMI can increase of exclusive breastfeeding practice.

\section{The association between maternal knowledge and exclusive breast- feeding}

The results of this study found a relationship between maternal knowledge and exclusive breastfeeding. Good knowledge can increase the likelihood of exclusive breastfeeding. Good knowledge provides an opportunity to increase exclusive breastfeeding (Isroni, 2013; Mogre et al., 2014; Alfianrisa et al., 2017). Good knowledge increased the chance of exclusive breastfeeding to infants three times as many than poor knowledge (Rachmad, 2011).

Exclusive breastfeeding practice that was based on knowledge had a longer effect (Alfianrisa et al., 2017). Good knowledge of exclusive breastfeeding motivates mothers to have a strong desire to breastfeed their infants as early as possible and continue to exclusively breastfeed until the age of 6 months (Gusti et al., 2011). In contrast, breastfeeding mothers who do not have sufficient knowledge of proper breastfeeding techniques and lactation management have a low desire to provide exclusive breastfeeding (Isroni, 2013).

The result of this study was consistent with the result of previous studies and the PRECEDE-PROCEED theory. Knowledge as a predisposing factor had a direct relationship with exclusive breastfeeding. Good lactating mothers had some insight into the benefits of exclusive breastfeeding, the effect of exclusive breastfeeding, and exclusive breastfeeding techniques. Mothers participating in the AIMI program had better knowledge than those not participating in the AIMI.

\section{The association between maternal attitude and exclusive breast- feeding}

The results of the analysis showed that there was a relationship between maternal attitude and exclusive breastfeeding. Mothers who had a positive attitude were more likely to exclusively breastfeed.

The result of this study was consistent with the result of previous studies showing that there was a relationship between positive attitude and exclusive breastfeeding (Gusti et al., 2011; Isroni, 2013; Vijayalakshmi et al., 2015).

A positive maternal attitude had a relationship with exclusive breastfeeding because a positive attitude raised awareness and motivation to continue to exclusively breastfeed to her infant (Gusti et al., 2011). The result of this study was somewhat different from that of Mogre et al. (2016) which found that maternal attitude might be advantageous in exclusive breastfeeding but not in itself brought about an optimal effect.

\section{The association between family support and exclusive breast- feeding}

The result of this study indicated that there was a direct relationship between family support and exclusive breastfeeding. Strong family support increased the likelihood of mothers giving exclusive breastfeeding. Family members' support such as help reflected good family function (Friedman, 2010).

The result of this study was consistent with the previous study which found that family support had a positive relationship 
with exclusive breastfeeding (Mannion et al., 2013; Kuniawati and Hargono, 2014; Nurlinawati et al., 2016; Alfianrisa et al., 2017).

The family support elements that are associated with exclusive breastfeeding include informational, instrumental, and emotional support (Nurlinawati et al., 2016). The instrumental family support provides facilities that fulfill the daily needs of mother and infant. The emotional elements of family support include praise, encouragement, and positive reinforcement, provided by the family members for the mother to exclusively breastfeed. The information elements of family support take the forms of advice, enlightenment, or adequate information, related to exclusive breastfeeding (Nurlinawati et al., 2016). Kurniawati and Hargono (2014) added that the success of exclusive breastfeeding is much influenced by families, especially husband, parent, relatives, friends, neighbors, and the environment. However, the greatest family support in exclusive breastfeeding practices comes from the husband. The husband can provide emotional support (Kurniawati and Hargono, 2014). The proximity of the husband can provide good emotional support such as encouragement and positive motivation in exclusive breastfeeding (Nurlinawati et al., 2016). Husband's support given in the form of verbal encouragement and active involvement in breastfeeding activities makes mothers more capable and confident to provide exclusive breastfeeding (Mannion et al., 2013). Professional support takes a variety of ways including direct, telephone, online arrangements, either in a group or individually (CDC, 2013).

The result of this study is consistent with the result of the previous study and the PRECEDE-PROCEED theory. According to Jolly et al. (2012), family support has a greater impact on exclusive breastfeeding in low- or middle-income countries.

\section{The association between maternal participation in AIMI and exclusive breastfeeding through maternal attitude}

The result of this study indicated there was a relationship between AIMI participation and exclusive breastfeeding through maternal attitude. The participation of AIMI increased the likelihood of mothers to have the positive attitude in exclusive breastfeeding.

One of the factors affecting low coverage of breastfeeding is a negative attitude. The negative attitude can stem from health promotion that has not been well implemented (Nancy, 2015). Gusti et al. (2011) found that exclusive breastfeeding promotion using counseling is a good method to improve exclusive breastfeeding by improving attitude. Counseling gives a serious attitude, empathy, and shows the desire to help, thus raising the belief of breastfeeding mothers to provide exclusive breastfeeding.

Mesters et al. (2013) found that breastfeeding education programs can lead to an average of $48 \%$ exclusive breastfeeding, increase knowledge, and a more positive attitude toward breastfeeding. In addition, breastfeeding education program can increase confidence and positive emotion in women. Mothers with a positive attitude have a greater chance of exclusive breastfeeding compared to mothers with a negative attitude (Vijayalakshmi et al., 2015).

Breastfeeding mothers will face many challenges in exclusive breastfeeding. Positive attitude, belief, intention, and support, are a source of maternal strength to breastfeed the infant. Participation in AIMI enhances the confidence of nursing mothers to exclusively breastfeed, due to 
Journal of Health Promotion and Behavior (2018), 3(1): 1-15

https://doi.org/10.26911/thejhpb.2018.03.01.01

the support of fellow lactating mothers. Breastfeeding mothers who participate in AIMI organization tend to imitate and follow the positive suggestion in their community (Alfianrisa et al., 2017).

\section{The association between maternal knowledge and exclusive breast- feeding through maternal attitude}

The result of this study indicated there was an indirect positive association between maternal knowledge and exclusive breastfeeding through maternal attitude. Higher maternal education increased the likelihood of positive maternal attitude in exclusive breastfeeding.

This study was consistent with Mogre et al. (2017) which reported that mothers who exclusively breastfed were more likely to have higher knowledge and positive attitude toward exclusive breastfeeding. This study is also consistent with Wowor et al. (2013), which stated that good knowledge would provide maternal experience in exclusive breastfeeding, as it would boost her confidence and attitude toward exclusive breastfeeding.

A change of attitude needs to be supported by better knowledge. A change in attitude can be made by informing mothers about the protective effect of exclusive breastfeeding against infection in children under five, as well as the beneficial effect of improving intelligence, and prevented overweight and diabetes in later life. For the lactating women, breastfeeding prevents them from breast cancer and improves birth spacing (Jain et al., 2017).

The results of Kurniawati and Hargono (2014) showed that mothers who did not understand about exclusive breastfeeding but exclusively breastfed can be attributed to the support of the nearest person or friend.

A positive attitude creates awareness and motivation to give exclusive breast- feeding. Increased knowledge encourages awareness and motivation, thus giving a change of attitude towards exclusive breastfeeding. Exclusive breastfeeding promotion with counseling method is the most appropriate method to improve mother's knowledge and attitude in exclusive breastfeeding (Gusti et al., 2011).

\section{The association between maternal education and exclusive breast- feeding through maternal attitude}

The results of this study indicate that there was a relationship between maternal education level and exclusive breastfeeding through attitude. A high level of maternal education increased the likelihood of a positive maternal attitude in exclusive breastfeeding.

The results of this study are consistent with other studies that found that high maternal education enhances exclusive breastfeeding (Isroni, 2013; Mogre et al., 2016; Wardani et al., 2017). High maternal education makes it easier for lactating mothers to catch information about exclusive breastfeeding (Gusti et al., 2011; Kurniawati and Hargono, 2014). Highly educated people tend to have broad access to information because they always want to know health information including exclusive breastfeeding information. Thus, higher education increases the likelihood of exclusive breastfeeding (Wardani et al., 2017).

The different findings were shown by Alfianrisa et al. (2017), Amraeni and Amiruddin (2010), and Kurniawati and Hargono (2014), which indicated that higher education reduced the possibility of exclusive breastfeeding. Mothers with higher education usually had activities outside the home that resulted in them leaving infants throughout the day. In contrast, low-educated mothers stayed at 
home more and thus had more chances to breastfeed infants.

Education is a basic need for selfdevelopment. The level of education may underlie the attitude of the mother in absorbing and changing the information system of exclusive breastfeeding. The higher the level of education, the greater the basic ability, the easier it is to receive information and knowledge, the higher the productivity and the family welfare (Isroni et al., 2013).

The results of this study are in accordance with PRECEDE-PROCEED theory, which stated that education and attitudes were related to exclusive breastfeeding behavior. Lactating mothers with low education are expected to follow AIMI's activities in order to increase self-confidence and to support the success of exclusive breastfeeding.

\section{The association between maternal education and exclusive breast- feeding through AIMI partici- pation}

The results of this study indicated an indirect relationship between maternal education and exclusive breastfeeding through AIMI participation. High maternal education increased the likelihood of AIMI participation and exclusive breastfeeding.

High maternal education is more receptive to new things and has good knowledge, so mothers follow AIMI activities. Participation in AIMI can enhance knowledge, insight, and information on exclusive breastfeeding so as to enhance exclusive breastfeeding. This study is consistent with Wardan et al. (2017) which explained that mothers with higher education tended to have better information access. Maternal education status allows the start of breastfeeding. Uneducated mothers should become the target of breastfeeding promotion strategies such as counseling and peer education (Acharya and Khanal, 2015). The results of this study are in accordance with the results of previous studies and also the PRECEDEPROCEED theory. According to this theory, education has a relationship with exclusive breastfeeding.

\section{The association between peer support and exclusive breastfeed- ing through family support}

The results of this study indicated there was a relationship between peer support with exclusive breastfeeding through family support. High peer support increased the likelihood of strong family support in exclusive breastfeeding.

Peer support affects exclusive breastfeeding (Kurniawati and Hargono, 2014). The support of the nearest family member (husband, parents, and siblings) and peer support (friends, neighbors, and neighbourhood) had a link to the exclusive breastfeeding (Kurniawati and Hargono, 2014).

Peer support generates ties with members of the group. They can share information related to exclusive breastfeeding and they feel valued. Support provided by friends and the family will provide positive assistance to lactating mothers. Family support is also a benchmark for the success of breastfeeding. In addition to the role of husbands, parents can influence mothers in exclusive breastfeeding because mothers are more likely to visit their parents than health workers to ask about the health problems of their babies (Grassley and Valerie, 2007). Peer support to the family allows individuals who gather together to solve problems and get results. Peer support increases the motivation, confidence, and capacity of women to resolve breastfeeding challenges (Thomson et al., 2015). 
Journal of Health Promotion and Behavior (2018), 3(1): 1-15

https://doi.org/10.26911/thejhpb.2018.03.01.01

The closest friend or person is the mother's strongest encouragement in giving exclusive breastfeeding. Shamans of peers who can exclusive breastfeeding include mothers seeing the growth of other children who are exclusively breastfed to their infants. Instead, the mother saw the friend giving the bottle to her child as the affected mother gave the bottle to her child. Bottlefeeding increases with the growing lifestyle of the community (Kurniawati and Hargono, 2014). Both peers and families provide support to lactating mothers to achieve exclusive breastfeeding. Mothers who get support from the family have a 3 times intention to give exclusive breastfeeding (Megawati, 2007).

The results of this study are in accordance with the results of previous studies and PRECEDE-PROCEED theories. Family support and peer support have a link to exclusive breastfeeding. Lactating mothers can increase the intensity to meet with neighbors and friends in the neighborhood and can participate actively in AIMI activities that can enable the lactating mothers to exchange stories about the experience during breastfeeding, thereby increasing the desire and behavior of lactating mothers to exclusively breastfeed.

\section{ACKNOWLEDGEMENT}

The author would like to extend gratitude to the Municipality Health Office Surabaya, the Indonesian Association of Lactating Mothers (AIMI) Surabaya, for the administrative support for this study.

\section{REFERENCE}

AbbaM, De Koninck M, Hamelin AM. (2010). A Qualitative Study of the Promotion of Exclusive Breastfeeding
By Health Professionals in Niamey, Niger. Int Breastfeed J, 5 .

Agunbiade OM, Ogunleye OV (2012). Constraints to Exclusive Breastfeeding Practice Among Breastfeeding Mothers in Southwest Nigeria: Implications for Scaling Up. International Breastfeeding Journal, 7(5).

Ajezen I (2005). Attitudes, Personality an Behavior. England: Open University Press.

Alfianrisa A, Salimo H, Pamungkasari EP. (2017). Factors Associated with Exclusive Breastfeeeding: Application of PRECEDE-PROCEED Model and Theory of Planned Behavior. Journal of Maternal and Child Health, 2(1): 42-53.

Ambarwati MR, Setiyani A, Usnawati N (2017). Efektifitas Kelas Diskusi ASI sebagai Media Promosi Kesehatan dalam Meningkatkan Praktik Menyusui. Jurnal Kesehatan, 10 (1).

Amraeni, Yunita, Amiruddin, Ridwan (2011). Immediate Breastfeding dan Pemberian Kolostrum Pada Program ASI eksklusif di Kendari. Jurnal Kedokteran Indonesia, 12(7):64-468.

Arisma dan Kaylaku S. (2012). Promoting \& Supporting Breastfeeding through Social Media: A Case Study From Indonesia Breastfeeding Mothers Association (AIMI). Asosiasi Ibu Menyusui Indonesia (AIMI).

Asosiasi Ibu Menyusui Indonesia (AIMI). (2017). htps://aimi-asi.org (accessed on 20 Juni 2017).

Centers For Disease Control And Prevention (CDC). (2013). The CDC Guide To Strategies To Support Breastfeeding Mothers And Babies. https://www.cdc.gov/breastfeeding/pdf/Strategy3Professional-Support.pdf. (accessed on 30 September 2017). 
Dinkes Kota Surabaya. (2015). Profil Kesehatan Kota Surabaya tahun 2015. Surabaya. Dinas Kesehatan Kota Surabaya.

DinKes Provinsi Jawa Timur. (2015). Profil Kesehatan Provinsi Jawa Timur Tahun 2015. Surabaya. Dinas Kesehatan Provinsi Jawa Timur.

Ekawati S, Parlindungan DR, Morita K (2015). Kampanye Program Pemberian ASI: Studi Deskriptif Implementasi Program Peningkatan Pemberian ASI Eksklusif di Kota Administrasi Jakarta Utara. Kalbisocio, 2(1).

Fikawati S, Syafiq A, Karima K. (2015). Gizi Ibu dan Bayi. Jakarta. Raja Wali Pers.

Friedman MM, Bowden O, Jones M. (2010). Buku Ajar Keperawatan Keluarga: Riset, Teori \& Praktik; alih bahasa, Achir Yani S. Hamid: editor Bahasa Indonesia, Estu Tiar, Ed. 5 . Jakarta:EGC.

Gupta N, Katende C, Bessinger R. (2004). An Evaluation of Post - Campaign Knowledge and Practices of Exclusive Breastfeeding in Uganda. Journal of Heald Population and Nutrition, Dec 22(4): 429-39.

Gusti D, Bachtiar H, Masrul M. (2011). Promosi ASI Eksklusif Memakai Metode Konseling dengan Penyuluhan terhadap Pengetahuan dan Sikap pada Ibu Menyusui. Jurnal Kesehatan Masyarakat Andalas, 6 (1).

Haroon S, Das JK, Salam RA, Imdad A, Bhutta ZA. (2013). Breastfeeding Promotion Interventions and Breastfeeding Practices: a Systematic Review. BMC Public Health,13 (20).

Helda. (2010). Kebijakan Pemberian ASI Eksklusif. Juran Kesehatan Masyaraakat, 3 (5).

Housniati. (2016). Kendala dan Tantangan Menyusui yang Paling Sering Dihadapi Masyarakat dan Peran AIMI sebagai Sebuah Organisasi Pendukung Ibu Menyusui dalam Memberikan Pendampingan dan Support kepada Para Ibu Menyusui untuk Sukses Memberikan ASI. Talkshow ASI. 24 Oktober. Lampung.

Irma N, dan Kustanti B. (2013). Efektivitas Comprehensive Breastfeeding Education terhadap Keberhasilan Pemberian Air Susu Ibu Postpartum. Padjadjaran Nursing Journal, 1(2).

Isroni A (2013). Determinan Pemberian ASI Eksklusif pada Ibu Menyusui. Jurnal Health 66 Quality, 4 (1): 1 76.

Jolly K, Ingram L, Khan KS, Deeks JJ, Freemantle N, MacArthur C (2012). Systematic Review of Peer Support for Breastfeeding Continuation: Meta regression Analysis of the Effect of Setting, Intensity, and Timing. BMJ, 344.

Khanal V, Sauer K, Zhao Y (2013). Exclusive Breastfeeding Practices in Relation to Social and Health Determinants: a Comparison of the 2006 and 2011 Nepal Demographic and Health Surveys. BMC Public Health, 13: 958.

Kruger R, Gericke G (2001). Breastfeeding Practices of Mothers with Children Age 0-36 in a Rural of South Africa. A Qualitative Approach. Journal of Family Ecology and Consumers Sciences, (29): 60-71.

Kurniawati D, Hargono R (2014). Faktor Determinan yang Mempengaruhi Kegagalan Pemberian ASI Eksklusif pada Bayi Usia 6-12 Bulan di Kelurahan Mulyorejo Wilayah Kerja Puskesmas Mulyorejo Surabaya. Jurnal Promkes Universitas Airlanga, 2(1): $15-27$.

Lakshmi, Triashtra (2011). Hubungan kelompok pendukung ibu terhadap perubahan perilaku menyusui di 
Journal of Health Promotion and Behavior (2018), 3(1): 1-15

https://doi.org/10.26911/thejhpb.2018.03.01.01

Kelurahan Banguntapan Kecamatan Banguntapan Kabupaten Bantul Di Yogyakarta. Tesis. Fakultas Kesehatan Masyarakat Universitas Indonesia.

Listyaningrum (2016). Tingkat pengetahuan dan Motivasi Ibu Berhubungan dengan pemberian ASI eksklusif pada ibu bekerja. Jurnal Ners dan Kebidanan Indonesia. DOI: http://dx.doi.org/10.21927/jnki.2016. 4(2).55-62. ISSN2354-7642.

Mannion CA, Hobbs AJ, McDonald SW, Tough SC (2013). Maternal Perceptions of Partner Support During Breastfeeding. International Breastfeeding Journal, 2013 8: 4.

Megawati D (2017). Analisis Jalur FaktorFaktor Sosial Ekonomi, Niat Ibu dan Kebijakan Perusahaan yang Berhubungan dengan Pemberian ASI Eksklusif Ibu Bekerja Di Perusahaan Kabupaten Klaten. Tesis. Universitas Sebelas Maret.

Mesters I, Gijsbers B, Bartholomew K, Knottnerus JA, Van Schayck OC. (2013). Social Cognitive Changes Resulting from an Effective Breastfeeding Education Program. Breastfeeding Medicine, 8 (1): 23 - 30.

Mogre V, Dery M, Patience K (2016). Knowledge, Attitudes and Determinants of Exclusive Breastfeeding Practice Among Ghanaian Rural Lactating Mothers. International Breastfeeding Journal, 11: 12.

Montgomery KS (2011). Maternalnewborn Nursing: Thirteen Challenges that Influence Excellence in Practice. The Journal of Perinatal Education 10 (1): 31- 40 .

Nancy LS (2015). Efektivitas Budaya Bakera sebagai Media Pengetahuan Ibu Nifas tentang ASI Eksklusif di Kota Bitung Provinsi Sulawesi Utara. JIKMU, 5 (2).
Nedesul. (2004). Makanan Bagi Bayi dan Anak. Jakarta: EGC.

Nurlinawati, Sahar J, Permatasari H (2016). Dukungan Keluarga terhadap Pemberian ASI Eksklusif pada Bayi di Kota Jambi. JMJ, 4 (1): 76 - 86.

Rachmad S. (2011). Hubungan pengetahuan ibu dengan kelangsungan pemberian ASI sampai anak berusia 2 tahun di wilayah kerja puskesmas kecamatan Kebayoran Lama Jakarta Selatan tahun 2011. Tesis. Fakultas Kesehatan Masyarakat Universitas Indonesia.

Shorea R, Agrina, Woferst R. (2013). Efektifitas Promosi Kesehatan melalui Audio Visual tentang Pemeriksaan Payudara Sendiri (Sadari) terhadap Peningkatan Pengetahuan Remaja Putri. Jurnal UNRI 1 (1).

Siregar (2014). Kampanye ASI Ekslusif Asosiasi Ibu Menyusui Indonesia.

Vijayalakshmi P, Susheela T, Mythili D (2015). Knowledge, Attitudes, And Breast Feeding Practices Of Postnatal Mothers: A Cross Sectional Survey. International Journal of Health Sciences. Qassim University, 9(4).

Wenzel D, Ocana RR, Maroto NG, Souza SB. (2010). A Multilevel Model for the Study of Breastfeeding Determinants in Brazil. Maternal Child Nutrition,6: $318-327$.

World Health Organization. (2017). World Breastfeeding Week. Mediacentre: World Health Organization (accessed on 8 September 2017).

Wowor M, Laoh JM, Pangemanan DHC. (2013). Hubungan Pengetahuan dan Sikap dengan Pemberian ASI Eksklusif pada Ibu Menyusui Di Puskesmas Bahu Kota Manado. Ejurnal keperawatan(e-Kp), 1 (1).

Wulandari ITTDRI (2015). Efektifitas Pendidikan Kesehatan Tentang ASI 
Handajani et al./ Effectiveness of Health Promotion by Indonesian Breastfeeding

Eksklusif terhadap Motivasi Ibu Hamil Trimester III dalam Pemberian asi Eksklusif di Wilayah Kerja
Puskesmas Jatiwates Kabupaten Jombang. Jurnal Kesehatan Masyarakat Poltek Kesehatan Majapahit. 